\title{
CLASSIFICATION OF FACTORS INFLUENCING ENVIRONMENTAL MANAGEMENT OF ENTERPRISE
}

\author{
Tatjana TAMBOVCEVA \\ Faculty of Engineering Economics and Management, Riga Technical University, \\ Kalnciema iela 6-213, LV-1048, Riga, Latvia
}

Received 20 August 2013; accepted 11 January 2014

\begin{abstract}
The modern enterprises consider the sustainable development as the one of basic conceptions of one's activity. In recent years, an increasing number of private as well as public organizations have been engaged with implementation and using of environmental management systems (EMSs). The research is built up by two main parts. In the first, author prepared theoretical analyses of literature and scientific publications. The second part based on survey results collected from Latvian companies using in depth interviews. Author proposes that the process of environmentally oriented business should be studied as a multi-dimensional issue. Company's external and internal environment elements were shown. In article author also investigated different factors influencing company's environmental management and motives of implementing EMS.
\end{abstract}

Keywords: environmental management, environmental management system, sustainable development, factors, analysis.

JEL Classification: Q01, Q56, 044.

\section{Introduction}

In according to "Agenda 21" what was held in Rio de Janeiro in 1992 and later such documents provide an appropriate quality of life nowadays and in the future is possible through the change-over of civilized world to the model of sustainable development (United Nations 1992). As stated by the Brundtland Report (Brundtland 1987), "How can we meet the needs of the present generation without compromising the ability of future generations to meet their needs"?

The UN Conference on Sustainable Development (Rio+20) what was held in Rio de Janeiro, Brazil June 20-22, 2012, to mark the 20th anniversary of the historic 1992 Rio Earth Summit, where was declared that an appropriate quality of life nowadays and in the future is possible through the change-over of civilized world to the model of sustainable develop-

Corresponding author Tatjana Tambovceva

E-mail: tatjana.tambovceva@rtu.lv 
ment. The official themes for Rio+20 were the green economy in the context of sustainable development and poverty eradication, and the institutional framework for sustainable development. At the close of the Rio+20 Earth Summit, heads of state and ministers from more than 190 nations signed off on a plan to set global sustainable development goals and other measures to strengthen global environmental management, tighten protection the oceans, improve food security and promote a "green economy".

Integrating sustainable development into the planning and measurement systems of business enterprises is not an easy task, because companies committed to incorporating sustainability concerns into product decisions are confronted with handling thousands of goods and materials. In this case is considered the environmental management (EM) what is an important instrument in achievement of the sustainable development and what oriented on making and realization of efficient management decisions which related to the provide an appropriate quality of an environment.

Ratings of organizations' environmental activities and capabilities influence billions of dollars of "socially responsible" investments as well as some consumers, activists, and potential employees. Because of the rise of an interest of society in a high level of the ecological security the EM is inculcates and advances by more and more enterprises. Environmental Management Systems (EMSs) have become an important tool for those organizations looking to manage their environmental issues such as legal compliance, pollution prevention, and minimizing the impacts their activities cause to the environment. An EMS considers a company's organization through a thorough review of operations, and analyses how a company's actions affect the environmental issues (ISO 14001:2004). After the literature review and made researches Tambovceva (2008) offers her own definition of the term: "Environmental management is the planning, implementation and control of strategic, tactical and operational measures for prevention, reduction and elimination of damage caused to the environment as well as purposeful usage of market advantages gained thereof". Many organizations present their environmental work in the form of annual reports and use the indicators in them for follow-up. In the first place enterprises are related with this problem because their production and commercial operations has significant affect to the environment. EM promotes the formation of a good image of enterprises (Poksinska et al. 2003; Zeng et al. 2005); the improvement of relations with public authorities and customer satisfaction (Hillary 2004; Zeng et al. 2005; Gavronski et al. 2008); effects the environmental, both positive (emission reductions) and negative (emissions generated) (Gilley et al. 2000). Generally hoped that implementation of ISO 14001 leads to both improved environmental management and economic competitiveness of the organization. However, it has been complex (Wagner et al. 2001). Similarly, the joint implementation of quality management and EM adds a series of benefits to those achieved by each of the systems alone such as: the alignment of goals, processes and resources and a reduction in the costs of internal and external audits; and the availability of joint training and improved communication between all organizational levels; an improvement in the efficiency and effectiveness of the organization, avoiding duplication of effort and reducing costs; a reduction of bureaucracy by eliminating duplication of policies, procedures and registers, see, for example, Zeng et al. (2007), Bernardo et al. (2009), Santos et al. (2011), Simon et al. (2011). Several studies 
argue that implementing an EMS demands time, money, and significant human resources involvement (Daily, Huang 2001; Šelih 2007). However it is necessary to improve management of an environmental activity of enterprises permanently for saving and accrual of these advantages in conditions of moving marketing area and providing effectiveness and stability of enterprises.

Different sources of data collection methodologies have been used, i.e., literature review of different question connected to EMS, and in-depth interview collected from the Latvian companies.

The purposes of the literature review are investigating of existing studies and develop a comprehensive whole picture of EMS development process. The aim of analytical research is to support studies of the influencing factors for EMS.

\section{Literature review}

Literature review was carried out in order to establish the theoretical background and practical examples from the international specialty literature, documents and reports of different research projects, own research works inclusively, and other information.

Early studies established a base from which organizations could consider "why it matters" (Porter, Van der Linde 1995; Hart, Ahuja 1996; Klassen, McLaughlin 1996). Later studies have attempted to establish a greater understanding of "how it works", focusing on either the strategic or operational functions of the organization and their relationship to environmental performance (Angell, Klassen 1999; Melnyk et al. 2003).

Many researchers evaluate how the implementation of EMS influences the environmental and financial performance, as well as barriers of implementation (Albertini 2013; Daddi et al. 2011b; Feng et al. 2016). Author agrees to Schaltegger and Synnestvedt (2002), they underlined that the relationship between EM and economic and environmental performance is complex. Some authors investigated approaches to measurement of sustainable development adopted by international organizations, or institutions (Grybaite, Tvaronavičiene 2008; Johnson 2013). A further complicating phenomenon is the fact that making optimal sustainability decisions requires evaluating sustainability in terms of environmental, social and economic aspects (Newman 2007; Midgley, Reynolds 2004). This complexity can be derived from the following definition of sustainability: "For the business enterprise, sustainable development means adopting business strategies and activities that meet the needs of the enterprise and stakeholders today while protecting, sustaining and enhancing the human and natural resources that will be needed in the future" (Business and Sustainable... 1992). Bakanauskienè et al. (2015) investigated environmental management strategies chosen by Lithuanian business organizations under the influence of environmental stakeholders. The results revealed the prevailing reactive strategies of environmental management determined by low environmental stakeholders' influence on business organizations when dealing with environmental issues. The persistent call for corporations to be socially and environmentally responsible originates from sustained pressure exerted by a range of stakeholders, including customers, communities, employees, governments and other (Epstein 2008; Hess, Warren 2008; Sarkar 2008; Daddi et al. 2011a). 
Evidence suggests that many organizations have taken an attenuated view of sustainability, being concerned with environmentally orientated topics such as eco-efficiency (Dyllick, Hockerts 2002). Cassel and Lewis (2011) explored the link between attitude and action through the examination of the interrelationship between awareness of environmental impact, attitude towards environmental issues, and environmental practice adoption. Berardi and de Brito (2015) investigated the environmental management process and analyzed the strength of the main environmental drivers in improving environmental practices in Brazilian firms.

Javier and Óscar Gonzalez-Benito (2010) investigated the effects of six relevant variables on stakeholder environmental pressure perceived by industrial companies: size, internationalization, location of manufacturing activities, position in the supply chain, industrial sector, and managerial values and attitudes.

Zemigala (2015) studied the main tendencies concerning the Environmental Management Systems' certification in the accordance with ISO 14001 and EMAS' registrations in the years 1999-2013 from a different countries' perspective. Bansal and Hunter (2003), as well as Darnall (2006) have evaluated the reasons why organizations adopt an EMS and the potential these environmental strategies have for improving the environment. In addition to that Steger (2000) took a review of smaller, mostly German, but also other European, empirical investigations of EMS in order to assess the impact that the EMSs have had on organizations.

Ählström et al. (2009) investigated articles about environment management published in Business Strategy and the Environment Journal during 2000-2006 and found that the majority of the articles do not reflect on its contribution to sustainable development and very few articles use alternative business models as examples.

Recent studies highlight pressures from government, customers and various stakeholder groups as triggers for firms to effectively incorporate sustainability issues into their supply chain management (SCM) schemes (Nawrocka 2008a, 2008b; Seuring, Müller 2008). To answer the environmental concerns of stakeholders, including customers, specific requirements need to be developed or the EMS needs to be customized, to accommodate environmental aspects connected to their own and suppliers' operations (Nawrocka 2008b).

Sarkar (2008) developed the conceptual model for theory building on corporate environmental behaviour, where summarized factors (market related factors, competitor responses, supply chain opportunities or restrictions, political and legal environment, pressure from NGOs, employees and the social environment, customer preferences and the long term goals of the firm) that need to be taken into account and underlined the dynamic nature of all these factors.

In a widely cited paper on environmental management strategies, Roome argues that the extent of a company's commitment to Corporate Environment Responsibility (as measured by "beyond compliance" behaviour) is influenced by a combination of external pressures and internal variables (Roome 1992). Paramount among the former are regulatory demands and liability risks, market opportunities and constraints, and broader stakeholder pressures. However, Roome argues that managerial attitudes also play an independent mediating role. A reactive managerial stance will focus the facility's efforts on legal compli- 
ance alone, while it takes a forward thinking approach to turn these external factors into "compliance plus" and a truly strong orientation to quality and commitment to innovation to produce environmental excellence.

For Ghobadian et al. (1998), in addition to external pressures/opportunities and managerial attitudes, an enterprise's environmental policies are also likely to be shaped by "moderating" (i.e. constraining) factors relating to a company's ability (human skills, financial resources, flexibility) to pursue a more ambitious environmental direction. They argue that such factors intervene between the external pressures and the capability of the company to address the activities necessary to develop successful environmental policies. The mediating factors fundamentally establish the interpretative framework that informs the decisionmaking process.

Fraj-Andrés et al. (2009) analyzed 235 industrial firms. The results reveal that competitive motivations and management commitment are the most important factors explaining why firms incorporate environmental issues into their strategic planning process. Moreover, management commitment is a critical factor for firms because managers' perception about customers' ecological concern directly influences firms' environmental behaviour. Kashmanian et al. (2010) investigated corporate environmental leadership: all drivers, characteristics, and gave some examples. De Oliveira (2013) developed Guidelines for the integration of certifiable management systems in industrial companies based on a theoretical framework and on the results from fourteen case studies performed in Brazilian industrial companies. The proposed guidelines were divided into three phases: A) integration planning, b) integration development, and c) integration control and improvement.

Many authors investigated different companies around the world to find out motives, barriers and benefits of implementation of EMS, experiences working with them and influencing factors (Goh et al. 2006; Gonzalez-Benito, J., Gonzalez-Benito, Ó. 2010; Khalid et al. 2002; Mori, Welch 2008; Morrow, Rondinelli 2002; Quazi 1999; Poksinska et al. 2003; Schylander, Martinuzzi 2007; Šelih 2007; Tambovceva, Geipele 2011; Welch et al. 2002; Zhang et al. 2008; Wiengarten et al. 2013; Kuei et al. 2013).

The most interesting for the author was Valentine's (2010) research. He presents a framework for guiding corporate environmental strategy to bring order to existing observations and allow social scientists to begin the process of "orderly control and prediction". The framework has been named the "Green Onion" to highlight the multiple strategic layers of influence uncovered and the importance of retaining resilient outer layers (i.e., stakeholder management) to protect the highly potent core of functional environmental management initiatives (i.e., cost saving initiatives).

\section{Data collection}

The study uses three data sources: (a) in-depth interviews with executives and experts; (b) access to internal documents (in-house information bulletins, environmental declarations, annual reports for the 2007-2011 period, etc.) as well as external sources (press, web pages, etc.); and (c) previous author's research experience connected with the environmental management and EMS. 
To explore Latvian organizations opinion in the field of different and most important factors influencing EM in the company a survey was used. In-depth interviews were conducted with 63 executives and experts who were all involved in the decision- making for their different Latvian companies environmental efforts. They were chosen mostly from companies with certified with ISO 14001 EMS, but not only. Basic data about certified organization count were taken from the Latvian Quality Association web-site. These interviews were conducted by the author, some in person via telephone and personal meetings. Each interview lasted about 30 to 45 minutes.

Respondents answered questions pertaining to the extent of involvement in environmental management, and the motives behind their organization's involvement in environmental initiatives. Each interview was based on the seminal question of the research: "What are the most important factors influencing your organization's environmental activity?" Then the interviewees were asked to concern the motives behind adopting environmental initiatives; which stakeholders placed these expectations on them. Participants were also encouraged to discuss the challenges and barriers that they perceived regarding implementation of their organizations' environmentally friendly efforts. The interviews allowed for an in-depth understanding of the participants' perspectives concerning their company's involvement in environmental initiatives. The qualitative analysis exhibit different external and internal factors, influencing the implementation of environmental, quality and safety issues in company's activities and find out most important of them.

\section{Research results and discussion}

The priorities of the 21st century were outlined in 1992 in Rio de Janeiro (Brazil), by declaring that "environmental management is to be considered the dominant of sustainable development and at same time the highest priority of production process and entrepreneurship". Environmental management is part of the concept of strategic management and involves safe management of economic activities that helps attain optimal correlation with efficient environmental protection. The goal of EM is to lessen the negative impact of economic activity on environment and to ensure ecological safety of production processes, as well as production of environmentally and to human health friendly production. Implementation of the given tasks has to go hand in hand with attainment of other priority goals of the company, including preservation of its current and long-term competitiveness. EM increases the liability of the company not only with regard production of safe and harmless products, but also with regard reasonable use of natural resources and selection of environmentally friendly technologies.

As it is known, development of environmental management in a company is influenced by many different factors. To identify such factors, the author has performed analysis of these factors after literature review and the interviews. All factors collected from the literature review and also mentioned by the respondents author collected in Figure 1 and divided in different groups. The author distinguishes between the following groups of factors: production - technical, economic, political - legal, organizational, ecological and risk factors, as well as education and culture level and mixed factors. The influencing factors are shown in Figure 1. 


\begin{tabular}{|c|c|c|}
\hline $\begin{array}{l}\text { Production - technical factors: } \\
\text { - equipment; tools; } \\
\text { - technologies; } \\
\text { - production design; } \\
\text { - process reorganization; } \\
\text { - produced goods; } \\
\text { - standardization. }\end{array}$ & $\begin{array}{l}\text { Ecological factors: } \\
\text { - changes in the ecological situation; } \\
\text { - changes in ecological privileges and norms; } \\
\text { - ecological certification; } \\
\text { - existence of eco passport; } \\
\text { - condition of company's territory and work } \\
\text { places. }\end{array}$ & $\begin{array}{l}\text { Political-legal factors: } \\
\text { - Legislati on changes; } \\
\text { - organizational } \\
\text { processes; } \\
\text { - budget funds; } \\
\text { - social policy. }\end{array}$ \\
\hline $\begin{array}{l}\text { Economic factors: } \\
\text { - produced production prices; } \\
\text { - resource prices; } \\
\text { - taxes; } \\
\text { - fines; } \\
\text { - price of licenses and permits; } \\
\text { - subsidies. }\end{array}$ & \multicolumn{2}{|c|}{$\begin{array}{l}\text { Risk factors: } \\
\text { - Market risk factors; } \\
\text { - Financial risk factors; } \\
\text { - Production risk factors; } \\
\text { - Technological factors; } \\
\text { - Technogenic risk factors; } \\
\text { - Human factor; } \\
\text { - Environmental legislation; } \\
\text { - Environmental dynamics; } \\
\text { - Entrepreneurship factors. }\end{array}$} \\
\hline $\begin{array}{l}\text { size of a company; } \\
\text { organizational structure of the } \\
\text { company; } \\
\text { results of ecological audit; } \\
\text { internal potential of the } \\
\text { company; } \\
\text { - quality management. }\end{array}$ & $\begin{array}{l}\text { Education and culture level } \\
\text { factors: } \\
\text { - personnel policy (qualification, } \\
\text { proficiency); } \\
\text { - information system; } \\
\text { - entrepreneurship ethics in cultural } \\
\text { and professional field. }\end{array}$ & $\begin{array}{l}\text { tors: } \\
\text { and technical progress; } \\
\text { on; } \\
\text { ation; } \\
\text { ia; } \\
\text { sessment. }\end{array}$ \\
\hline
\end{tabular}

Fig. 1. Factors influencing implementation of environmental management in a company

The actual multiplicity of practically applicable environmental management models depends on listing of different specific factors. These factors influence both the inclusion of company's ecological aspects and the functioning efficiency of environmental management models. However, it must be stressed that environmental protection activity management and organization in specific forms depend on the conception of general management used in the particular company. In the result of elaboration of the topic of the article it was established that a company, as an object of environmental management has both external (macro) and internal (micro) environments. Thereof, environmental behavior of companies depends on some internal and some external forces. Talking about external and internal environment elements, we are talking about different stakeholders.

Several classifications of stakeholders exist. One of the most widely accepted definitions has been proposed by Freeman (1984: 46) as "any individual or groups who can affect or is affected by the achievement of the organization's objectives". Stakeholders may influence managerial perception by means of two instruments: pressure and cooperation. For instance, Clarkson (1995) as well as Carroll and Buchholtz (2011) distinguished between primary stakeholders (i.e., shareholders, investors, employees, suppliers, customers etc.) and secondary stakeholders (i.e., media, consumers, pressure groups, competitors, general public etc.), according to the existence or the absence of a formal contractual relationship between the company and those stakeholders.

Primary stakeholders are seen as absolutely necessary for the survival of a business, while secondary stakeholders affect and are affected by the company but are not essential for its survival. On the other hand, researchers such as Henriques and Sadorsky (1999) proposed a typology based on the stakeholders' functions and their relative power on the 
organization. They distinguished between (a) regulatory stakeholders (e.g., governments and trade associations), (b) organizational stakeholders (e.g., customers, suppliers, employees, and shareholders), (c) community stakeholders (i.e., NGOs and social groups), and (d) the media. This latter conceptualization has been retained in the European Business Environmental Barometer - the international survey concerning environmental management practices of manufacturing companies.

The environmental management literature has argued that firms undertake environmental actions to answer stakeholders' pressures. Valentine (2010) described five broad categories emerged from the coding process as dominant forces which influence how a company approaches the development of environmental management initiatives - macro elements, secondary stakeholder elements, industry-specific elements, firm specific elements and functional elements.

In strategic management theory, macro forces are referred to as PEST forces: Political, Economic, Social and Technological. The relevant tenet is that the PEST forces in each country influence the extent to which firms within industries approach environmental governance (Kolk 2005). Some analysts added Legal and Environmental/ecological factors expanded it to PESTEL or PESTLE.

In the result of elaboration of the topic of the article it was established that a company, as an object of environmental management has both external (macro) and internal (micro) environments. Thereof, environmental behaviour of companies depends on some internal and some external forces. Author proposes that the process of environmentally oriented business should be studied as a multi-dimensional issue and suggests dividing company's external environment into two levels - Broad (Macro) Environment and Task (Micro) Environment. The external environment (both broad and task environments), which consists of specific elements (clients, cooperation partners, state institutions, competitors etc.), influence company's internal environment in all its functional subsystems. Company's management system introduces changes in the subsystems in response to changes in the external environment. All the elements of the internal environment provide all system functions, i.e. activities of all other subsystems. External environment influences the common management system of the company and consequently also environmental management. To better illustrate all the elements of the external and internal environment, the author of the paper has created a scheme embracing the elements of company's external and internal environment, displayed in Figure 2.

The different environmental factors that affect the company can be broadly categorized as external and internal its factors. The Broad (Macro) Environment consists of global factors:

1. Political Factors: tax policy, labour law, environmental law, trade restrictions, tariffs, and political stability. Political factors may also include goods and services which the government wants to provide or be provided and those that the government does not want to be provided.

2. Economic Factors: growth rate, interest rates, taxation changes, economic growth, inflation, energy prices, exchange rates, unemployment. These factors have major impacts on how businesses operate and make decisions. 


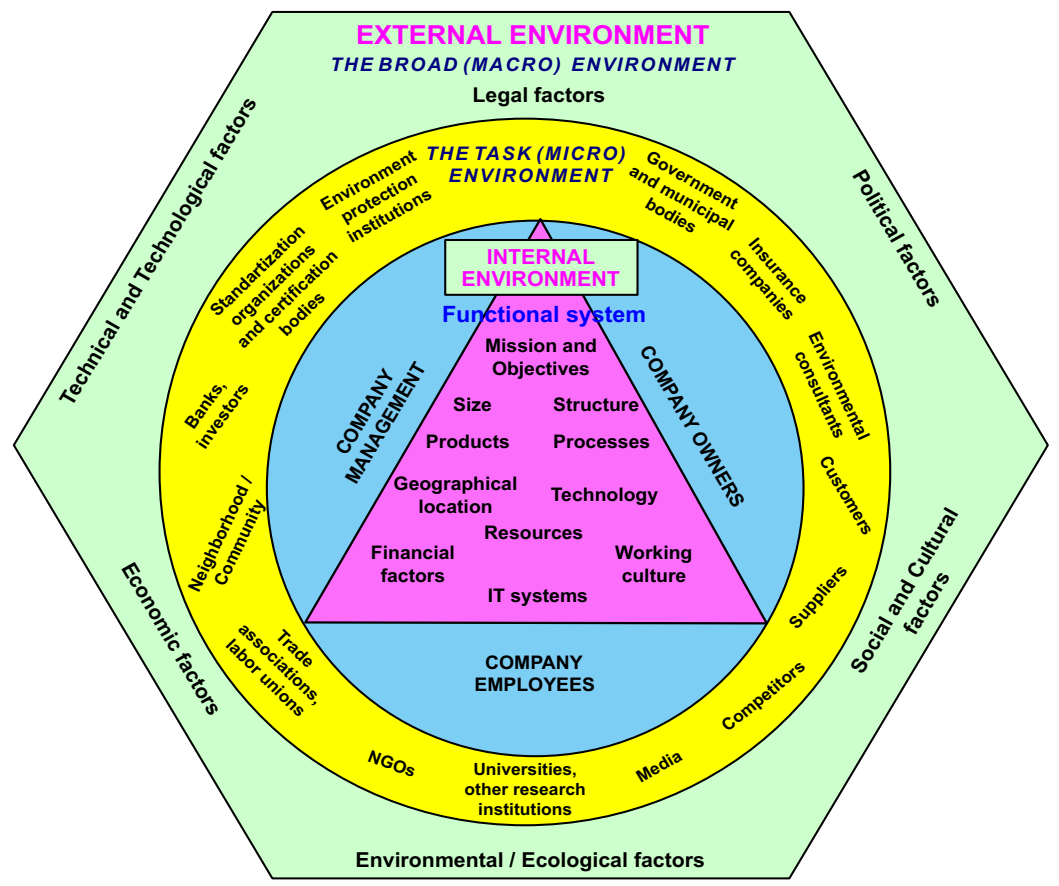

Fig. 2. Company's external and internal environment elements

3. Social and Cultural Factors: Demographic changes, age distribution, patterns of work, career attitudes and emphasis on safety, household structure, patterns of consumption, gender roles cultural aspects and health consciousness etc. Trends in social factors affect the demand for a company's products and how that company operates.

4. Technical and Technological Factors: R\&D activity, technology development, automation, technology incentives and the rate of technological change, online shopping, bar coding and computer aided design etc. They can determine barriers to entry, minimum efficient production level and influence outsourcing decisions. Furthermore, technological shifts can affect costs, quality, and lead to innovation.

5. Environmental/Ecological Factors: ecological and environmental aspects such as weather, climate, and climate change, environmental conditions and information etc.

6. Legal Factors: legislations: employment law, consumer law, discrimination law, health and safety law, antitrust law etc.; trading relationships, regulation, permissions. These factors can affect how a company operates, its costs, and the demand for its products.

The Task (Micro) environment consists of stakeholders with whom organizations interact on a fairly regular basis. These stakeholders include domestic and international customers, suppliers, competitors, government agencies and administrators, local communities, activist groups, unions, and financial intermediaries.

A company's internal environment is composed of the elements within the organization, including the conditions, entities, events, and factors that are generally under the control 
of the company and influence its activities and choices, particularly the behaviour of the employees. Factors that are frequently considered part of the internal environment include the organization's mission statement and objectives, leadership styles, its organizational and corporate culture, and manufacturing (quality).

Taking into account company's external and internal environment elements (see in Fig. 2) there are factors in each of these groups that can be assessed by means of respective indicators. The external factors influencing a company can be divided into two subgroups:

- Indirect impact factors: economic, technical and technological, political, international, social, education and culture factors, environmental situation, relationship with local inhabitants (indirect impact environment);

- Direct impact factors: customers, competitors, suppliers, labour resources of the society, laws and state regulatory services etc. (direct impact environment).

At the company level, general company features, such as product type, size, position in the product chain, and geographical location, are potential influencing factors for environmental management, as are factors such as environmental strategy, responsibilities, and IT systems.

In total, approx. 30 one-hour, interviews with key facility personnel demonstrate the most important factors for influencing environmental management activities (see Table 1). Respondents answered to the question "Assess the actual influence on the company from the following stakeholders when considering/deciding to undertake an environmental initiative (please, check only one box for each stakeholder)?" Respondents believed to provide organizations with advantages in different areas (i.e., enhancing reputation, addressing demands and expectations of customers, mitigating negative media reports, and developing a stronger network of partners resulting in deeper linkages into the communities in which these organizations operate). A number of executives discussed the cost savings associated with being environmentally conscious in facility operations in particular. Turning off lights at practice and facilities, adjusting the thermostat were all identified as substantial cost saving measures.

Table 1 reports on the influence of stakeholders on company level environmental practices. Using the "Heavy influence" column, it can be seen that public authorities, management employees, company owners, non-management employees and investors have the greatest influence. With the exception of public authorities, all these stakeholders can be categorized as internal to the company in that they each have a stake in the company's survival (for example, employees - their job and investors - their investment). Note that insofar as the "product chain stakeholders" are concerned, household consumers were not perceived as having a heavy influence.

Respondents mentioned different motives of implementing EMS, such as prevention or control environmental incidents; ensuring of legal compliance; improving of company image; customer pressure/expectation; cost savings; new technology or new product development; improving of internal organization and documentation; increased market opportunities, i.e. competitive advantages; improving of environmental performance; motivation of the staff and employee welfare; following head office environmental practices and achievement of continuous environmental improvement. Table 2 summarizes respondent's motives for undertaking environmental practices. 
Table 1. Influencing factors on the Environmental Practices of the company

\begin{tabular}{|c|c|c|c|c|}
\hline $\begin{array}{l}\text { Influence on the environmental practices } \\
\text { of your company by: }\end{array}$ & $\begin{array}{c}\text { No } \\
\text { influence }\end{array}$ & $\begin{array}{c}\text { Little } \\
\text { influence }\end{array}$ & $\begin{array}{c}\text { Some } \\
\text { influence }\end{array}$ & $\begin{array}{c}\text { Heavy } \\
\text { influence }\end{array}$ \\
\hline \multicolumn{5}{|l|}{ Regulatory Authorities } \\
\hline Public authorities (government, municipal) & $1.59 \%$ & $4.76 \%$ & $28.57 \%$ & $65.08 \%$ \\
\hline \multicolumn{5}{|l|}{ Investors } \\
\hline Shareholders and investment funds & $17.46 \%$ & $20.63 \%$ & $28.57 \%$ & $33.33 \%$ \\
\hline Banks and other lenders & $23.81 \%$ & $15.87 \%$ & $33.33 \%$ & $26.98 \%$ \\
\hline \multicolumn{5}{|l|}{ External Stakeholders } \\
\hline Environmental groups or organisations & $23.81 \%$ & $11.11 \%$ & $44.44 \%$ & $20.63 \%$ \\
\hline Industry or trade associations & $23.81 \%$ & $17.46 \%$ & $42.86 \%$ & $15.87 \%$ \\
\hline Labour unions & $26.98 \%$ & $44.44 \%$ & $17.46 \%$ & $11.11 \%$ \\
\hline Competitors & $12.70 \%$ & $20.63 \%$ & $23.81 \%$ & $42.86 \%$ \\
\hline Neighbourhood/community groups & $20.63 \%$ & $19.05 \%$ & $31.75 \%$ & $28.57 \%$ \\
\hline Local environmental initiatives & $3.17 \%$ & $87.30 \%$ & $7.94 \%$ & $1.59 \%$ \\
\hline Press/media & $7.94 \%$ & $38.10 \%$ & $42.86 \%$ & $11.11 \%$ \\
\hline Scientific institutions & $79.37 \%$ & $11.11 \%$ & $7.94 \%$ & $1.59 \%$ \\
\hline \multicolumn{5}{|l|}{ Product Chain stakeholders } \\
\hline Household consumers & $33.33 \%$ & $23.81 \%$ & $26.98 \%$ & $15.87 \%$ \\
\hline Commercial buyers & $26.98 \%$ & $9.52 \%$ & $36.51 \%$ & $26.98 \%$ \\
\hline Suppliers of goods and services & $38.10 \%$ & $7.94 \%$ & $42.86 \%$ & $11.11 \%$ \\
\hline \multicolumn{5}{|l|}{ Company internal environment } \\
\hline Company owners & $4.76 \%$ & $19.05 \%$ & $25.40 \%$ & $50.79 \%$ \\
\hline Management employees & $3.17 \%$ & $4.76 \%$ & $36.51 \%$ & $55.56 \%$ \\
\hline Non-management employees & $7.94 \%$ & $12.70 \%$ & $42.86 \%$ & $36.51 \%$ \\
\hline
\end{tabular}

Table 2. Motives to undertake environmental practices in the company

\begin{tabular}{lcccc}
\hline \multicolumn{1}{c}{ Motivations } & $\begin{array}{c}\text { Not } \\
\text { important }\end{array}$ & $\begin{array}{c}\text { Slightly } \\
\text { important }\end{array}$ & $\begin{array}{c}\text { Moderately } \\
\text { important }\end{array}$ & $\begin{array}{c}\text { Very } \\
\text { important }\end{array}$ \\
\hline Improve company image & $0.00 \%$ & $3.17 \%$ & $19.05 \%$ & $77.78 \%$ \\
\hline Ensure regulatory compliance & $1.59 \%$ & $3.17 \%$ & $28.57 \%$ & $66.67 \%$ \\
\hline Customer pressure/expectation & $9.52 \%$ & $15.87 \%$ & $38.10 \%$ & $36.51 \%$ \\
\hline Cost savings & $7.94 \%$ & $26.98 \%$ & $34.92 \%$ & $30.16 \%$ \\
\hline Improve manufacturing process & $6.35 \%$ & $17.46 \%$ & $36.51 \%$ & $39.68 \%$ \\
\hline Improve internal organization and documentation & $6.35 \%$ & $19.05 \%$ & $39.68 \%$ & $34.92 \%$ \\
\hline Competitive advantages/market opportunities & $11.11 \%$ & $23.81 \%$ & $34.92 \%$ & $30.16 \%$ \\
\hline Prevent or control environmental incidents & $7.94 \%$ & $9.52 \%$ & $31.75 \%$ & $50.79 \%$ \\
\hline Improve environmental performance & $14.29 \%$ & $19.05 \%$ & $34.92 \%$ & $31.75 \%$ \\
\hline Following head office environmental practices & $3.17 \%$ & $15.87 \%$ & $39.68 \%$ & $41.27 \%$ \\
\hline Employee welfare & $12.70 \%$ & $39.68 \%$ & $34.92 \%$ & $12.70 \%$ \\
\hline
\end{tabular}


The number one motivation (using the "very important" column) is regulatory compliance followed by the prevention or control of environmental incidents, corporate profile/ image and cost savings. New technology or product development and the fact that similar facilities are adopting similar practices were not critical motivators. From a managerial perspective, the latter should be of concern if such activities are not being undertaken or viewed as important because managers view such activities as threats rather than opportunities.

The most significant motive for implementing EMS was "corporate image". The next highest valued motives for an implementation were: ensure regulatory compliance and prevent and control environmental incidents, as well as improving of manufacturing process. This indicates that Latvian organizations are primarily expecting external benefits from an EMS implementation.

The results cited above tell us that regulatory authorities play a very important role in motivating facilities to undertake environmental practices. The next section builds on this result by suggesting the possible expansion of public environmental policy to programmes that encourage the development of environmental management systems.

EMSs, just like any other systems, include many interconnected elements, which are inseparable within the given system. All elements have their own specifics, features and tasks, own structure, functions and behaviour. Taking into account the eco paradigm, which is even more applicable for company's activities, it is necessary to develop and integrate into the joint structure of the company the environmental management system. The author proposes development of such a system by using the model, which is shown in Figure 3.

Environmental Management System covers all management functions and types: strategic, tactical and operational/ functional. The developed model prescribes that company's management has to include ecology related components in all management functions, by respectively integrating ecopolicy, ecostrategy and ecological programs in the EMS what allows the company produce innovative products by observing ecological requirements in all production stages. Integration of environmental management into the collective management system of the company allows reduce time for processing documentation for eco passport, development of the planned technologies, as well as helps create ecological services. Thereby it is possible to considerably promote planning of development processes.

On the basis of the previous analysis the author has concluded that without definite, precisely formulated action plan on strategic, tactical as well as operational level, the attainment of company's political, social and commercial goals is rather cumbersome or even practically impossible. Environmental management foresees mandatory involvement in deliberate, purposeful and ecological activities of not only individual specialists, but also managers and decision takers as well as the entire production personnel and parties interested in the ecological activities of the company.

Another aspect of equal importance concerning the issue of reaching personnel's' recognized "ecological" activities is explanation of the chosen environmental policy of the company to all employees, respective training and implementation of due practical training activities for the personnel. Implementation of the developed environmental policy, organisation of respective campaigns and activities in the company has to be performed by the respective ecological service or by the responsible employees. 


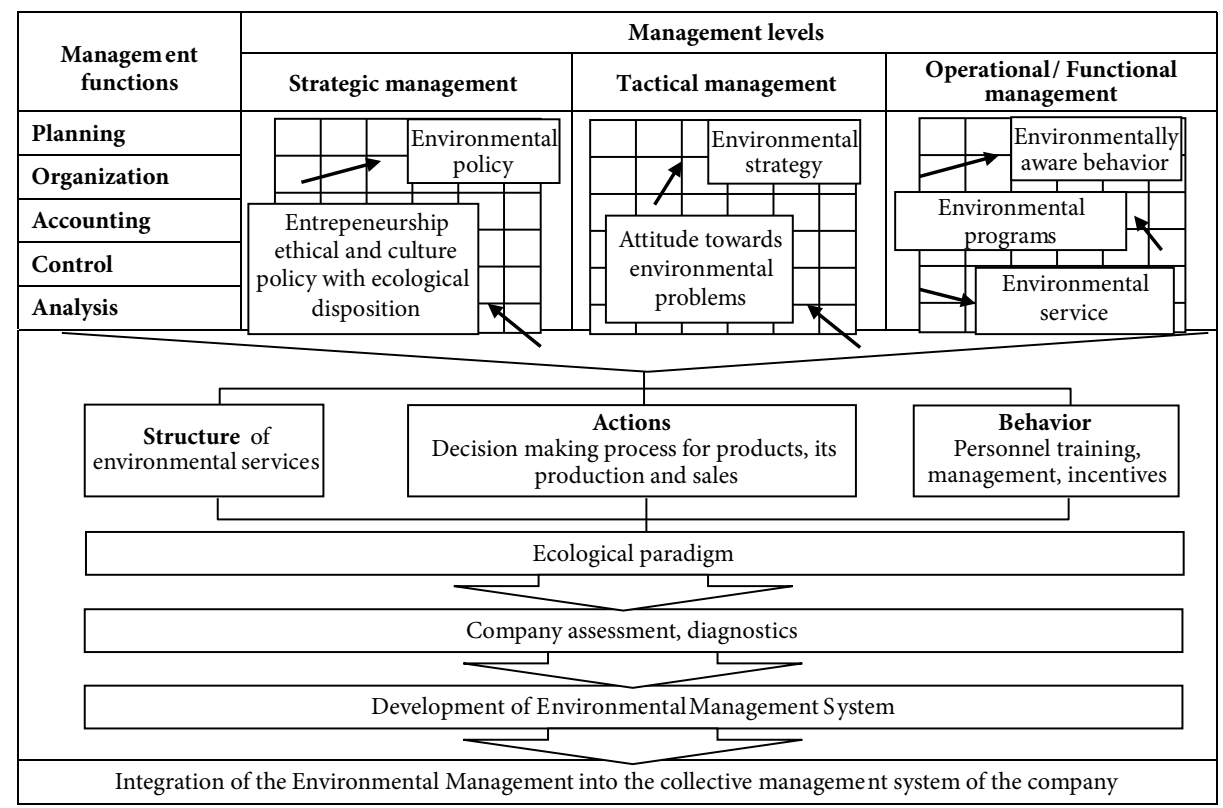

Fig. 3. Model for integration of Environmental Management into the collective management system of a company

\section{Conclusions, proposals, recommendations}

The main results of the research and the conclusions deriving thereof are as follows.

1. The need for application of environmental management is determined by the ecological situation, which changes in the result of commercial activities of companies. As for today all level organizational systems for environmental management are: state, regional, municipal as well as company, public organization and on interpersonal level. It is necessary to increase efficiency of management efforts in the field of company environmental activity.

2. The author of the research is convinced of the importance of integration of the environmental management system in the management systems of companies because the factors of the surrounding environment are among the most important external factors that can strongly influence company's activity in general. The environmental management system cannot be efficient without interacting with other company's systems and subsystems.

3. Environmental management system on company level is part of the entire management structure of the company, including organizational structure, setting of responsibilities and implementation of environmental policy. The functioning of the environmental management system, according to the author, has to be based on function hierarchy by considering the level of urgency of the solutions. Urgent and immediate management measures are defined by preventive and operational environmental management, whereas measures that can be postponed - by tactical and 
strategic management. Thus, environmental management is an art of making efficient management decisions to increase efficient usage of natural resources and environmental protection within the conditions of the relevant market.

4. Environmental management has to be studied from the system access positions and has to reflect the interaction between ecological problem awareness, elaboration of appropriate public policy and development of an ecological strategy in the company. The results indicate that the effect of variables such as company size, internationalization, industrial sector and managerial values on the formulation and implementation of environmental strategies might be due, at least partially, to their effects on perceived stakeholder environmental pressure.

This contribution is original because this study develops a comprehensive whole picture of this path process, which has previously only been partially discussed in the literature. The analytical research presented here aims to support studies of the influencing factors for EMS. During the development of this research have provided valuable real-life input, but the study should not be seen as complete and further studies are likely to add more to it.

\section{Acknowledgements}

The author acknowledges the financial support provided by Riga Technical University Nr. ZP-2012/23/D2/ for this research.

\section{References}

Ählström, J.; Macquet, M.; Richter, U. 2009. The lack of a critical perspective in environmental management research: distortion in the scientific discourse, Business Strategy and the Environment 18(5): 334-346. http://dx.doi.org/10.1002/bse.592

Albertini, E. 2013. Does environmental management improve financial performance? A meta-analytical review, Organization and Environment 26(4): 431-457. http://dx.doi.org/10.1177/1086026613510301

Angell, L. C.; Klassen, R. D. 1999. Integrating environmental issues into the mainstream: an agenda for research in operations management, Journal of Operations Management 17(5): 575-598. http://dx.doi.org/10.1016/S0272-6963(99)00006-6

Bakanauskienè, I.; Staniulienė, S.; Žirgutis, V. 2015. Strategies of environmental management in Lithuanian business organizations: in response to environmental stakeholders context, Management of Organizations: Systematic Research 74: 7-23. http://dx.doi.org/10.7220/MOSR.2335.8750.2015.74.1

Bansal, P.; Hunter, T. 2003. Strategic explanations for the early adoption of ISO 14001, Journal of Business Ethics 46(3): 289-299. http://dx.doi.org/10.1023/A:1025536731830

Berardi, P. C.; de Brito, R. P. 2015. Drivers of environmental management in the Brazilian context, Brazilian Administration Review 12(1): 109-128. http://dx.doi.org/10.1590/1807-7692bar2015140038

Bernardo, M.; Casadesus, M.; Karapetrovic, S.; Heras, I. 2009. How integrated are environmental, quality and other standardized management systems? An empirical study, Journal of Cleaner Production 17(8): 742-750. http://dx.doi.org/10.1016/j.jclepro.2008.11.003

Brundtland, G. 1987. Our common future: report of the World Commission on Environment and Development. Oxford University Press: Oxford, 247 p.

Business and Sustainable Development: a Global Guide [online]. 1992 [cited 25 October 2012]. Available from Internet: http://www.bsdglobal.com/pdf/business_strategy.pdf 
Carroll, A. B.; Buchholtz, A. K. 2011. Business and society: ethics and stakeholder management. 8th ed. Cincinnati: South-Western Publishing, 888 p.

Cassells, S.; Lewis, K. 2011. SMEs and environmental responsibility: do actions reflect attitudes?, Corporate Social Responsibility and Environmental Management 18(3): 186-199.

http://dx.doi.org/10.1002/csr.269

Clarkson, M. B. E. 1995. A stakeholder framework for analyzing and evaluating corporate social performance, The Academy of Management Review 20: 92-117.

Daddi, T.; Frey, V.; Iraldo, F.; Nabil, B. 2011a. The implementation of an environmental management system in a North-African local public administration: the case of the City Council of Marrakech (Morocco), Journal of Environmental Planning and Management 54(6): 813-832. http://dx.doi.org/10.1080/09640568.2010.537543

Daddi, T.; Magistrelli, M.; Frey, M.; Iraldo, F. 2011b. Do environmental management systems improve environmental performance? Empirical evidence from Italian companies, Environment, Development \& Sustainability 13(5): 845-862. http://dx.doi.org/10.1007/s10668-011-9294-8

Darnall, N. 2006. Why firms mandate ISO 14001 certification, Business and Society 45(3): 354-381. http://dx.doi.org/10.1177/0007650306289387

Daily, B. F.; Huang, S. 2001. Achieving sustainability through attention to human resource factors in environmental management, International Journal of Operations \& Production Management 21(12): 1539-1552. http://dx.doi.org/10.1108/01443570110410892

De Oliveira, O. J. 2013. Guidelines for the integration of certifiable management systems in industrial companies, Journal of Cleaner Production 57: 124-133.

http://dx.doi.org/10.1016/j.jclepro.2013.06.037

Dyllick, T.; Hockerts, K. 2002. Beyond the business case for corporate sustainability, Business Strategy and the Environment 11(2): 130-141. http://dx.doi.org/10.1002/bse.323

Epstein, M. J. 2008. Making sustainability work: best practices in managing, and measuring corporate social, environmental, and economic impacts. Sheffield, UK: Greenleaf Publishing, 288 p.

Feng, T.; Cai, D.; Wang, D.; Zhang, X. 2016. Environmental management systems and financial performance: the joint effect of switching cost and competitive intensity, Journal of Cleaner Production 113: 781-791. http://dx.doi.org/10.1016/j.jclepro.2015.11.038

Fraj-Andrés, E.; Martḳnez-Salinas, E.; Matute-Vallejo, J. 2009. Factors affecting corporate environmental strategy in Spanish industrial firms, Business Strategy and the Environment 18(8): 500-514. http://dx.doi.org/10.1002/bse.611

Freeman, E. 1984. Strategic management: a stakeholder approach. London: Pitman, 276 p.

Gavronski, I.; Ferrer, G.; Paiva, E. 2008. ISO 14001 certification in Brazil: motivations and benefits, Journal of Cleaner Production 16(1): 87-94. http://dx.doi.org/10.1016/j.jclepro.2006.11.002

Gilley, K.; Worrell, D.; El-Jelly, A. 2000. Corporate environmental initiatives and anticipated firm performance: the differential effects of process-driven versus product-driven greening initiatives, Journal of Management 26(6): 1199-1216. http://dx.doi.org/10.1177/014920630002600607

Ghobadian, A.; Viney, H.; Lui, J.; James, P. 1998. Extending linear approaches to mapping corporate environmental behavior, Business Strategy and the Environment 7(1): 13-23. http://dx.doi.org/10.1002/(SICI)1099-0836(199802)7:1<13::AID-BSE133>3.0.CO;2-D

Goh, E. A.; Suhaiza, Z.; Nabsiah, A. W. 2006. A study on the impact of environmental management system (EMS) certification towards firms' performance in Malaysia, Management of Environmental Quality: An International Journal 17(1): 73-93. http://dx.doi.org/10.1108/14777830610639459

Gonzalez-Benito, J.; Gonzalez-Benito, Ó. 2010. A study of determinant factors of stakeholder environmental pressure perceived by industrial companies, Business Strategy and the Environment 19(3): 164-181. http://dx.doi.org/10.1002/bse.631 
Grybaite, V.; Tvaronavičiene, M. 2008. Estimation of sustainable development: germination on institutional level, Journal of Business Economics and Management 9(4): 327-334. http://dx.doi.org/10.3846/1611-1699.2008.9.327-334

Hart, S. L.; Ahuja, G. 1996. Does it pay to be green? An empirical examination of the relationship between emission reduction and firm performance, Business Strategy and the Environment 5(1): 30-37. http://dx.doi.org/10.1002/(SICI)1099-0836(199603)5:1<30::AID-BSE38>3.0.CO;2-Q

Henriques, I.; Sadorsky, P. 1999. The relationship between environmental commitment and managerial perceptions of stakeholder importance, Academy of Management Journal 42(1): 87-99. http://dx.doi.org/10.2307/256876

Hess, D.; Warren, D. E. 2008. The meaning and meaningfulness of corporate social initiatives, Business and Society Review 113(2): 163-197. http://dx.doi.org/10.1111/j.1467-8594.2008.00317.x

Hillary, R. 2004. Environmental management systems and the smaller enterprise, Journal of Cleaner Production 12(6): 561-569. http://dx.doi.org/10.1016/j.jclepro.2003.08.006

ISO 14001:2004. Environmental management system: requirements with guidance for use. International Organization for Standardization. $32 \mathrm{p}$.

Johnson, M. P. 2013. Sustainability management and small and medium-sized enterprises: managers' awareness and implementation of innovative tools, Corporate Social Responsibility and Environmental Management 22(5): 271-285. http://dx.doi.org/10.1002/csr.1343

Kashmanian, R.; Keenan, C.; Wells, R. 2010. Corporate environmental leadership: drivers, characteristics, and examples, Environmental Quality Management 19(4): 1-20. http://dx.doi.org/10.1002/tqem.20259

Khalid, A. B.; Robert, A. B.; Matthew, F. 2002. Critical factors for implementing ISO14001 standard in United Sates industrial companies, Journal of Cleaner Production 11: 749-752.

Klassen, R. D.; McLaughlin, C. P. 1996. The impact of environmental management on firm performance, Management Science 42(8): 1199-1214. http://dx.doi.org/10.1287/mnsc.42.8.1199

Kolk, A. 2005. Environmental reporting by multinationals from the Triad: convergence or divergence?, Management International Review 45: 145-166.

Kuei, C.; Chow, W. S.; Madu, C. N.; Wu, J. P. 2013. Identifying critical enablers to high performance environmental management: an empirical study of Chinese firms, Journal of Environmental Planning and Management 56(8): 1152-1179. http://dx.doi.org/10.1080/09640568.2012.716364

Melnyk, S.; Sroufe, R.; Calantone, R. 2003. Assessing the impact of environmental management systems on corporate and environmental performance, Journal of Operations Management 21(3): 329-351. http://dx.doi.org/10.1016/S0272-6963(02)00109-2

Midgley, G.; Reynolds, M. 2004. Systems/operational research and sustainable development: towards a new agenda, Sustainable Development 12(1): 56-64. http://dx.doi.org/10.1002/sd.218

Mori, Y.; Welch, E. W. 2008. The ISO 14001 environmental management standard in Japan: results from a national survey of facilities in four industries, Journal of Environmental Planning and Management 51(3): 421-445. http://dx.doi.org/10.1080/09640560801979683

Morrow, D.; Rondinelli, D. 2002. Adopting corporate EMSs: motivations and results of ISO 14001 and EMAS certification, European Management Journal 20(2): 159-171. http://dx.doi.org/10.1016/S0263-2373(02)00026-9

Nawrocka, D. 2008a. Inter-organizational use of EMSs in supply chain management: some experiences from Poland and Sweden, Corporate Social Responsibility and Environmental Management 15(5): 260-269. http://dx.doi.org/10.1002/csr.150

Nawrocka, D. 2008b. Environmental supply chain management, ISO 14001 and RoHS. How are small companies in the electronics sector managing?, Corporate Social Responsibility and Environmental Management 15(6): 349-360. http://dx.doi.org/10.1002/csr.176 
Newman, L. 2007. The virtuous cycle: incremental changes and a process-based sustainable development, Sustainable Development 15(4): 267-274. http://dx.doi.org/10.1002/sd.317

Poksinska, B.; Dahlgaard, J.; Eklund, J. 2003. Implementing ISO 14000 in Sweden: motives, benefits and comparisons with ISO 9000, International Journal of Quality and Reliability Management 20(5): 585-606. http://dx.doi.org/10.1108/02656710310476543

Porter, M. E.; Van der Linde, C. 1995. Toward a new conception of the environment-competitiveness relationship, The Journal of Economic Perspectives 9(4): 97-118. http://dx.doi.org/10.1257/jep.9.4.97

Quazi, H. A. 1999. Implementation of an environmental management system: the experience of companies operating in Singapore, Industrial Management \& Data System 99(7): 302-311. http://dx.doi.org/10.1108/02635579910262526

Roome, D. 1992. Developing business environmental strategies, Business Strategy and the Environment 1(1): 11-24. http://dx.doi.org/10.1002/bse.3280010104

Santos, G.; Mendes, F.; Barbosa, J. 2011. Certification and integration of management systems: the experience of Portuguese mall and medium enterprises, Journal of Cleaner Production 19(17-18): 1965-1974. http://dx.doi.org/10.1016/j.jclepro.2011.06.017

Sarkar, R. 2008. Public policy and corporate environmental behaviour: a broader view, Corporate Social Responsibility and Environmental Management 15(5): 281-297. http://dx.doi.org/10.1002/csr.167

Schaltegger, S.; Synnestvedt, T. 2002. The link between green and economic success: environmental management as the crucial trigger between environmental and economic performance, Journal of Environmental Management 65(4): 339-346. http://dx.doi.org/10.1006/jema.2002.0555

Schylander. E.; Martinuzzi, A. 2007. ISO 14001: experiences, effects and future challenges: a national study in Austria, Business Strategy and the Environment 16(2): 133-147. http://dx.doi.org/10.1002/bse.473

Seuring, S.; Müller, M. 2008. From a literature review to a conceptual framework for sustainable supply chain management, Journal of Cleaner Production 16(15): 1699-1710.

http://dx.doi.org/10.1016/j.jclepro.2008.04.020

Simon, A.; Bernardo, M.; Karapetrovic, S.; Casadesus, M. 2011. Integration of standardized environmental and quality management systems audits, Journal of Cleaner Production 19(17-18): 20572065 http://dx.doi.org/10.1016/j.jclepro.2011.06.028

Steger, U. 2000. Environmental management systems: empirical evidence and further perspectives, European Management Journal 18(1): 23-37. http://dx.doi.org/10.1016/S0263-2373(99)00066-3

Šelih, J. 2007. Environmental management systems and construction SMEs: a case study for Slovenia, Journal of Civil Engineering and Management 13(3): 217-226.

Tambovceva, T. 2008. Assessment models and development of ecologically oriented entrepreneurship management in Latvia. Doctoral Thesis, Riga Technical University. 192 p.

Tambovceva, T.; Geipele, I. 2011. Environmental management systems experience among Latvian construction companies, Technological and Economic Development of Economy 17(4): 595-610. http://dx.doi.org/10.3846/20294913.2011.603179

United Nations. 1992. Agenda 21, in United Nations Conference on Environment and Development (UNCED), 3-14 June 1992, Rio de Janerio, Brazil. 351 p.

Valentine, S. V. 2010. The green onion: a corporate environmental strategy framework, Corporate Social Responsibility and Environmental Management 17(5): 284-298. http://dx.doi.org/10.1002/csr.217

Wagner, M.; Schaltegger, S.; Wehrmeyer, W. 2001. The relationship between the environmental and economic performance of firm, Greener Management International 34(1): 94-111.

http://dx.doi.org/10.9774/GLEAF.3062.2001.su.00009 
Welch, E. W.; Mori, Y.; Aoyagi-Usui, M. 2002. Voluntary adoption of ISO 14001 in Japan: mechanism, stages and effects, Business Strategy and the Environment 11(1): 43-62. http://dx.doi.org/10.1002/bse.318

Wiengarten, F.; Pagell, M.; Fynes, B. 2013. ISO 14000 certification and investments in environmental supply chain management practices: identifying differences in motivation and adoption levels between Western European and North American companies, Journal of Cleaner Production 56: 18-28. http://dx.doi.org/10.1016/j.jclepro.2012.01.021

Zeng, S.; Tam, C.; Tam, W.; Deng, Z. 2005. Towards implementation of ISO 14001 environmental management systems in selected industries in China, Journal of Cleaner Production 13(7): 645-656. http://dx.doi.org/10.1016/j.jclepro.2003.12.009

Zeng, S. X.; Shi, J. J.; Lou, G. X. 2007. A synergetic model for implementing an integrated management system: an empirical study in China, Journal of Cleaner Production 15(18): 1760-1767. http://dx.doi.org/10.1016/j.jclepro.2006.03.007

Zemigala, M. 2015. Environmental management systems - European perspective, Regional Formation and Development Studies 3(17): 169-180. http://dx.doi.org/10.15181/rfds.v16i3.1130

Zhang, B.; Bi, J.; Yuan, Z. W.; Ge, J. J.; Liu, B. B.; Bu, M. L. 2008. Why do firms engage in environmental management? An empirical study in China, Journal of Clean Production 16(10): 1036-1045. http://dx.doi.org/10.1016/j.jclepro.2007.06.016

Tatjana TAMBOVCEVA. Doctor, Professor at the Faculty of Engineering Economics and Management of Riga Technical University, Latvia. Member and expert in a number of international Societies, Councils and Foundations.

Author and co-author of more than 100 scientific and other publications, and 10 books. Research interests focus on environmental management and sustainable development; corporate social and environmental responsibility; green production and consumption, change of consumer behaviour; sustainable building, real estate management, project management and use of computers in many areas. 